\title{
Conflict between Self and Society in Hemingway's Short Fiction
}

\section{Ritu Rani}

\author{
Lecturer in English, Aarohi Model Senior Secondary School, Fathebad, India
}

\begin{abstract}
Hemingway's Fiction depicts the conflict between self and society. It also presents the hero's antagonism towards society's traditional values and superimposed morality. Contrary to his unmitigated cosmic skepticism, however his relation with human society undergoes a continuous change. Hemingway highlights the peculiar stresses and dilemmas of the protagonist and his revolt against society. He has consistently refused to become an instrument in the hands of the society that teats man no better than a mere thing. Hemingway depicts the alienated protagonist trying desperately to recover from traumatic experiences of war. It is was which has made the hero realize the meaninglessness of traditional moral values of society as a result of which he has lost every sense of identification with people around him. Thus Hemingway sees his problematic hero in light of the interaction between self and society.
\end{abstract}

Keywords: Conflict, antagonism oscillation, individual, society, protagonist, crisis, war.

\section{Conflict between Self AND Society in Hemingway's Short Friction}

Hemingway's fiction depicts the conflict between self and society as well as the hero's antipathy towards the chaos and disorder prevalent in society due to two world wars. It also presents the hero's antagonism towards society's traditional values and superimposed morality. Man's relation to the cosmos and the short individual's relation to society are the major preoccupations of Hemingway short fiction, and both projected in the twin problems of his hero whose development is seem primarily in relation to these two issues. As to his relation to the cosmos, the hero remains a skeptic until the end; throughout he continues to distrust abstract philosophies, and he constantly explores himself to life experiences. Contrary to his unmitigated cosmic skepticism, however, his relation with human society undergoes a continuous change. At one level, it is a problem of identity, for the hero's continuous search for a meaningful relationship with society is a search, too, for his own identity. But while he finds a definite role in his heroic service to society, he also discovers in its rigid pattern a threat to his individual self. The result is continuous oscillation between solitude and society: while some short stories show "the hero's promethean attempts to serve the large causes of humanity, some stories portray his recoil from that promethean role". ${ }^{1}$ In fact, the Hemingway hero fights against the society and its institutions which try to impose their traditional values on him. He has boundless confidence in his powers and feels that a man is the shaper of his own destiny.

At another level the hero's concern with society reveals his changing dreams and illusions for its improvement, which is a broader concern than mere search for identity. Hemingway's short fiction can be taken as the best illustration of the hero's developing attitude towards society. As Nick Adams, the hero of some of short stories, recalls that he had seen in war an opportunity to become the savior of mankind. But each attempt the Hemingway hero makes to serve a social cause ends in frustration, and he withdraws from society into his private world. As a critic points out, "This withdrawal, too, is paradoxical; on the one hand it gives freedom and quietude, on the other it makes him feel socially guilty. Hence his continuous oscillation between self and society". But the fact of the matter is that this oscillation does not imply an absence of development in the hero's awareness of life.

Hemingway has shown his protagonist in the post-war world. On the one hand Hemingway focuses attention on protagonist's rootlessness and bewilderment in a world sapped out of its nourishing resources of spirit and meaningful enterprise, and on the other hand Hemingway's short stories highlight the tragic aftermath of war in which man's responses and attitudes were mercilessly conditioned as much by the gory spectacle of war itself as by its total and chaotic consequences of human civilization at large. For Hemingway's contemporaries also the post-war years were years of searing trauma that made the future of mankind dubious and provoked man to protest against 
traditional social values. There is no dearth of literary specimens during the twenties and thirties which voice the confusion and the dilemma of man amidst a set of sociological features which tended to wipe out all that was precious and beautiful in human civilization. This terrible destiny of man mapped out by Hemingway in his short stories, and the themes that he chose allow the predicament of man to voice itself without frill. It is in the short stories that Hemingway began to shape his hero, "the 'macho' figure desperately trying to redeem himself through self-knowledge, exemplifying that quality of courage Hemingway describes as 'grace under pressure'." Such a protagonist by the very nature of his circumstances defies moral judgments in terms of commonly accepted norms of behavior.

Hemingway highlights in his short stories the peculiar stresses and dilemmas of the protagonist and his revolt against society. He has intended in his short fiction to mirror the tragic consciousness of a war-torn generation of which the protagonists in many ways are the lonely products. The hero's revolt against society is due to an overwhelming degree of Hemingway's experience in world war 1 . Hemingway's experience was of a disillusioned man by the war. He returned from war to society whose values seemed to him hollow and artificial by comparison with harsh realities of the battlefield. For example, Harold krebs, the hero of "Soldier's Home," is sickened by the brutality of war, and decides to revolt against society's artificial and hollow norms. The Hemingway hero, on the whole, is a man besieged by the predicament of our modern world, especially the age of the two world wars. Yet what gives him a significant place as here are the basic qualities of courage, endurance and the will to strive against the odds of life. He is quite often a fighter, and in his struggle to redeem himself, he is usually destroyed. He is not afraid of death, but he hates the idea of accepting death as a solution to life's problems.

The tragic sense of life is constantly present in all the short stories of stories of Hemingway. The tragic sense not only throws the zest of life into relief but gives it much content and meaningless world and the Hemingway heroes make efforts to establish their selfhood, freedom and identity in the incoherent and meaningless universe. They encounter with life which is full of shocking and horrified experiences of violence, death and nada. John Atkin very aptly describes the human condition when he says, "you know that death is waiting, so you know that hope is a mirage. Even those people who win their hopes are frustrated in the end, for once you have got the thing you want you wish to keep it and that is impossible. ${ }^{3}$

Hemingway's early stories demonstrate the face that the Hemingway hero starts his journey of life full of expectation and hope to discover the meaning of life. In the course of journey his experiences remove the mask of life and so that the life is essentially tragic and full of violence and death. Hemingway has recorded truthfully and painfully Nick Adams' experiences in this world in his early short stories. Nick's experience in the war had brought him face to face to face with a terrifying reality and resulted in the complete negation of all the traditional values of religion, faith and philosophy that till then had sustained him. He realized that

There is no help available beyond the individual's own self....

Man stands alone, horrifying alone, cut off from God and men.

$\mathrm{He}$ is not a member of spiritual or temporal society wherein any reciprocal benefits are bestowed. ${ }^{4}$

In a society where every framework has collapsed, it is not possible to redeem oneself by any collective action. It is the lone individual who can seek his own salvation, by his refusal to accept defeat by reasserting his individuality through desperate acts of courage and reaffirm faith in himself.

Hemingway focuses attention on the protagonist's bewilderment, and rootlessness in the chaotic society. He also shows his protagonist in the post- war world where he finds himself completely alienated and purposeless. As Ray B. West suggests that the Hemingway works deal with the "condition of man in a society upset by the violence of war." ${ }^{, 5}$ Perhaps heming way could visualize no clear-cut solutions to the problem confronting society and he, consequently became more concerned with the individual. He has consistently refused to become an instrument in the hands of a society that treats man no better than a mere thing. The Hemingway hero is trapped biologically: he sings a separate peace, and as an aftermath he suffers from a feeling of truancy.

In most of the stories the Hemingway protagonist asserts himself in the face of tremendous odds and it is his will to struggle that gives him heroic proportions. Hemingway puts his protagonist in situations 
when he has to rely completely on his inner resources and in this way brings out his important inner character. His protagonist always remains busy in his single- minded pursuit of courage and in his obstinate attempts to prove himself. In some stories, the Hemingway protagonists are ageing professionals - boxers, bullfighters or fishermen - who despite their age, show tremendous will power by their unwillingness to give up; and it is their effort to prove themselves despite their limitations that all the more increases their heroic stature. As Arthur Wald horn asserts that

From the outset, Hemingway's protagonists are visited in a world of natural and human violence, struggling to survive and to assert the integrity of self. ${ }^{6}$

In Hemingway's short fiction we also find the hero's changing response to human society, human relationships, human values and his growing outlook on life that lie at the center of Hemingway's work and imparts to his entire short fiction a significant unity. The development of Hemingway's art is more closely linked with the development of his "Progressive hero", ${ }^{7}$ who grows from Nick Adams to Francis Macomber of "The Short Happy Life of Francis Macomber" and Harry of "The Snows of Kilimanjaro". These stories deal with hero's relations with his father and mother, his concern for human relationships and values, and his individual antagonism towards society's evils etc. In most of stories the protagonist has been presented facing with the actualities of the society and human condition - a puzzling and disillusioning place in which beauty and wonder, love and compassion, are strangely mixed with cruelty, violence, suffering, loss, alienation and death. As Jackson J. Benson rightly points out, "The world as it actually is in Hemingway's short fiction set against man's expectations and hopes; and his consequent problems and difficulties in trying to love in it with meaning and order". 8 The heroes in these stories are characterized by their unflinching integrity. They do not compromise. They are vulnerable but are not defined by their vulnerability. Hemingway feature men and women facing both death and emotional crisis with grit, gumption and grand tenacity. His men and women are often defiant of what society expects of them; they eat with gusto, devour adventure and have sex - simply and directly.

Hemingway explores in his short fiction how Nick matures and how he vows never to bow to fear is central to the crisis in each story. He depicts the alienated protagonist trying desperately to recover from traumatic experiences of war. It is war which has made the hero realize the meaninglessness of traditional moral values of society as a result of which he has lost every sense of identification with people around him. He cannot remain indifferent and the only way open to him is to reject this meaningless pattern of society. As James B. Colvert rightly points out:

The Hemingway hero rejects the finality of conventional values because he can discover in them no relevancy to moral realities, and the ramification of his rejection encompasses not only the traditional attitudes towards values, but the very principle underlying them. This traditional approach to value is based upon the unquestioned assumption that sound values judgment can be made through abstract formulation of conventional moralizing. Values are determined as absolutes and are conceived as metaphysical realities apart from any relation to the physical world apprehensible to the senses... (He realizes that ) the war after all is only a violent surface manifestation of a moral rapture splitting the whole social body. So long as the society insist upon a moral double standard then society must be rejected if there is to be any hope for a reconstruction of values.'

Hemingway sees his problematic hero in the light of the interaction between self and society. From the first volume of short fiction In Our Time, to the last, The Old Man and the Sea, a novella, the problematic hero unsuccessfully attempts to make sense of liberal values in the society which denies freedom for him. Hemingway's this problematic protagonist is oppressed by social pressures; he has become a little passive due to war-injuries and sometimes remain cloistered in his imagination, taking to world's veneer at its face value. Such an attitude makes the hero opposite to the society and his consciousness finds no consolation in the world of conventions and inauthentic values.

If one were to examine literature with a view to tracing some major themes that have inspired it, "the conflict between self and society" would certainly be one of them. Undoubtedly it is a universal 


\section{Ritu Rani}

theme, for an individual human being always wants to meet his demands and society wants to prevent him to meet these demands. Society has its own traditions and conventions and an individual does not like to tie himself up with these conventions. As Aristotle articulates that 'man is born free but everywhere he finds himself in chains'. And Hemingway's short fiction seems to be concerned privately with the desire to know who he was; and various critics have perceived Hemingway's 'quest for self and self's conflict with society' in his short stories.

\section{REFERENCES}

[1] Bhim S. Dahia, The Hero in Hemingway: A Study in Development (Chandigarh: Bahri Publications Private Ltd., 1978) P.16

[2] Syed Ali Hamid, The Short Fiction of Ernest Hemingway A Study in Major Themes (New Delhi, Ashish Publishing House, 1985) viii.

[3] John Atkin, The Art of Ernest Hemingway (London :Spring Books, 1952) P.140

[4] Jackson J. Benson, Hemingway : The Writer's Art of Self Defense (Minneapolis : University of Minnesota Press, 1969) P.140

[5] Ray B. West, "The Biological Trap", Hemingway "A Collection of Critical Essays, ed. Robert P. Weeks (Engle wood Cliffs, N.J. : Prentice Hall, 1962) P.139

[6] Arthur Wald horn, A Reader's Guide to Ernest Hemingway ( New York: Farrar, Straus and Giroux; 1971) P.5

[7] Jackson J. Benson, ed. The Short Stories of Ernest Hemingway : Critical Essays (Durham, North Carolina, Duke University Press, 1975) P.29-53

[8] Benson, The Short Stories of Ernest Hemingway, P. 24

[9] James B. Colvert, Ernest Hemingway's Morality in Action:, American Literature, 27(November 1955) P.374-76 